\title{
Phytochemical Constituents and Antibacterial Activities of Hibiscus sabdariffa L. Calyces (Zobo Flower) Extracts on Escherichia coli and Staphylococcus aureus
}

\author{
Unegbu V Nnachetam ${ }^{1}$, Okey-Ndeche Florence ${ }^{2}$, Obum-Nnadi Charity ${ }^{3}$, Egwuatu Pius ${ }^{4}$
}

\begin{abstract}
Introduction: Hibiscus sabdariffa plant has been used in many ways both for industrial purposes and medicinal uses. It has been discovered to have antimicrobial properties.

Aim and objective: The present study was aimed to investigate the phytochemical and antimicrobial activities of methanolic and aqueous extracts of H. sabdariffa calyces on Staphylococcus aureus and Escherichia coli.

Materials and methods: The phytochemical analysis was carried out using standard methods. The antibacterial activity of the plant extracts was determined using the agar well diffusion method. The minimum inhibitory concentration (MIC) and minimum bactericidal concentration (MBC) of the plant extracts on the test isolates were determined using the micro broth dilution method.

Results: The phytochemical analysis showed that terpenoids, phenols, flavonoids, glycosides, tannin, saponin, alkaloids, and anthraquinolones were present in varying concentrations of the different extracts. The methanol extract of $H$. Sabdariffa calyces possesses more antimicrobial activity $(13-24 \mathrm{~mm})$ in a concentration-dependent manner than the aqueous extract $(7-20 \mathrm{~mm})$. The MIC of different extracts of $S$. aureus was between $25 \mathrm{mg} / \mathrm{mL}$ and $50 \mathrm{mg} / \mathrm{mL}$ while that of $E$. coli was also between $12.5 \mathrm{mg} / \mathrm{mL}$ and $25 \mathrm{mg} / \mathrm{mL}$. The MBC of different extracts of $S$. aureus was between 25 and $50 \mathrm{mg} / \mathrm{mL}$ while that of $E$. coli was between 6.25 and $50 \mathrm{mg} / \mathrm{mL}$.

Conclusion: It can be concluded that some secondary metabolites present in $\mathrm{H}$. sabdariffa calyces was responsible for the observed inhibition of the bacteria seen in this study. The methanol extract of $\mathrm{H}$. sabdariffa calyces possesses more antimicrobial activity in a concentration-dependent manner than the aqueous extract. Therefore, the test plant could be used to manufacture drugs that could be used to treat infections caused by the test organisms.

Keywords: Aqueous, Escherichia coli, Hibiscus sabdariffa, Methanol, Staphylococcus aureus.

Journal of Health Sciences \& Research (2020): 10.5005/jp-journals-10042-1092
\end{abstract}

\section{INTRODUCTION}

The plant Hibiscus sabdariffa, commonly called "Roselle" and "Zobo" in Nigeria, belongs to the family Malvaceae. ${ }^{1}$ It is an annual or perennial herb or woody-based subshrub, growing to $2-2.5 \mathrm{~m}$ (7-8 feet) tall. The leaves are deeply three- to five-lobed, $8-15 \mathrm{~cm}$ (3-6 in.) long, arranged alternately on the stems.

The flowers are 8-10 cm (3-4 in.) in diameter, white to pale yellow with a dark red spot at the base of each petal, and have a stout fleshy calyx at the base, $1-2 \mathrm{~cm}(0.39-0.79 \mathrm{in}$.) wide, enlarging to $3-3.5 \mathrm{~cm}$ (1.2-1.4 in.), fleshy and bright red as the fruit matures. They take about 6 months to mature. ${ }^{2}$

Among the Yoruba in southwest Nigeria, Roselle is known as isapa, and yakuwa by the Hausa people of northern Nigeria who also call the seeds as gurguzu and the capsule cover as zoborodo or zobo. ${ }^{1}$

Hibiscus sabdariffa plant has been used in many ways both for industrial purposes and medicinal uses. It has been incorporated in the treatment of many ailments such as hypertension, arterioclerosis, neurosis, cancer, etc. ${ }^{3}$ It has also been used for many industrial products. In India, the plant is primarily cultivated for the production of bast fiber used in cordage, made from its stem. ${ }^{4}$ The fiber may be used as a substitute for jute in making burlap. ${ }^{4}$ Hibiscus, specifically roselle, has been used in folk medicine as a diuretic and mild laxative. ${ }^{4}$

The red calyces of the plant are increasingly exported to the United States and Europe, particularly Germany, where they are used as food colorings. It can be found in markets (as flowers
${ }^{1}$ Department of Microbiology, Spiritan University Nneochi, Abia State, Nigeria

2,3 Department of Microbiology, Veritas University, Abuja, Nigeria

${ }^{4}$ Department of Microbiology, Renaissance University, Ugbawka, Enugu State, Nigeria

Corresponding Author: Unegbu V Nnachetam, Department of Microbiology, Spiritan University Nneochi, Abia State, Nigeria, Phone: +2348035402207, e-mail: donval4u@yahoo.com

How to cite this article: Nnachetam UV, Florence O-N, Charity O-N, et al. Phytochemical Constituents and Antibacterial Activities of Hibiscus sabdariffa L. Calyces (Zobo Flower) Extracts on Escherichia coli and Staphylococcus aureus. J Health Sci Res 2020;11(1):12-16.

Source of support: Nil

Conflict of interest: None

or syrup) in places, such as France, where there are Senegalese immigrant communities. ${ }^{5}$ The green leaves are used like a spicy version of spinach. They give flavor to the Senegalese fish and rice dish thieboudienne. Proper records are not kept, but the Senegalese government estimates national production and consumption at 700 t (770 short tons) per year. ${ }^{5}$

A tea made from Hibiscus flowers is known by many names around the world and is served both hot and cold. The beverage is known for its red color, tart, flavor, and vitamin $\mathrm{C}$ content. ${ }^{6}$ 
In Nigeria, rosella jam has been made since colonial times and is still sold regularly at community fetes and charity stalls. ${ }^{7}$ It is similar in flavor to plum jam, although more acidic. It differs from other jams in that the pectin is obtained from boiling the interior buds of the rosella flowers. It is thus possible to make rosella jam with nothing but rosella buds and sugar. ${ }^{8}$

The plant has been used in the treatment of many ailments and used in many folk medicines. ${ }^{9}$ The Hibiscus leaves are a good source of polyphenolic compounds. The major identified compounds include neochlorogenic acid, chlorogenic acid, cryptochlorogenic acid, caffeoylshikimic acid, and flavonoid compounds such as quercetin, kaempferol, and their derivatives. ${ }^{9}$ The flowers are rich in anthocyanins, as well as protocatechuic acid. The dried calyces contain the flavonoids gossypetin, hibiscetine, and sabdaretine. ${ }^{10}$ The major pigment, formerly reported as hibiscin, has been identified as daphniphylline. Small amounts of myrtillin (delphinidin 3-monoglucoside), chrysanthenin (cyanidin 3-monoglucoside), and delphinidin are present. Roselle seeds are a good source of lipidsoluble antioxidants, particularly gamma-tocopherol. ${ }^{11}$

Previously published studies have shown that it has significant antibacterial activity against Bacillus cereus, Staphylococcus epidermidis, Staphylococcus aureus, Escherichia coli, Pseudomonas aeruginosa, Salmonella enterica, Klebsiella pneumonia, Proteus vulgaris, etc. ${ }^{12}$

Therefore, the aim of this study is to evaluate the phytochemical and antibacterial activities of $H$. sabdariffa leaf extracts on $E$. coli and S. aureus.

\section{Materials and Methods}

\section{Sample Collection}

The flowers of $H$. sabdariffa (Zobo flowers) were bought from Ogbete market in Enugu State, Nigeria, and were authenticated by a botanist at the Nnamdi Azikiwe University Herbarium with a voucher number of NAUH 27A.

The preparation was done at the microbiology laboratory of Spiritan University, Nneochi, Abia State. The fresh flowers of $H$. sabdariffa were washed thoroughly with clean water, cut into bits, and placed in a washed tray to air dry. ${ }^{13}$ With the help of a pestle and mortar, it was crushed to coarse powder. Different containers were used to label and store the powdered form of the leaves.

\section{Test Organisms}

The antibacterial test organisms used were bacterial cultures of E. coli and S. aureus obtained from the laboratory section of the Department of Microbiology, Nnamdi Azikiwe University, Anambra State, Nigeria. Standard methods, i.e., cultural, morphological, and biochemical tests, were used to confirm their identity. ${ }^{14}$ Agar slants were used to maintain the bacterial isolates at $4^{\circ} \mathrm{C}$ until further use.

\section{Biochemical Identification of the Test Organism Escherichia coli}

The E. coli from the test culture was placed on Eosine Methylene Blue (EMB) agar for 24 hours. A positive result for E. coli was indicated with the appearance of colonies with green metallic sheen. The distinct colonies with metallic green sheen on EMB agar were picked and confirmed by streaking onto the Chromagar E. coli medium (Oxoid, Basingstoke, UK). Colonies with a blue/violet appearance were selected and analyzed further by gram staining and biochemical tests. $^{14}$

\section{Staphylococcus aureus}

Staphylococcus aureus that showed positive result for the catalase test was subcultured on blood agar and incubated at $37^{\circ} \mathrm{C}$ for 24 hours. Then, the single colonies were placed on Mannitol Salt Agar (MSA) for 24 hours. A positive result was indicated by smooth circular colonies with yellow color. ${ }^{14}$

\section{Standardization of the Tests Organisms}

The test organisms (E. coli and S. aureus) were standardized by the use of 24-hour-old broth cultures prepared by inoculating the test organisms into $5 \mathrm{~mL}$ of nutrient broth and the culture was incubated for 2 hours. The growth of the organism was indicated by the turbid change in color of the nutrient broth, which was adjusted to match the color of the 0.5 McFarland turbidity equivalent standards. ${ }^{14}$

\section{Preparation of Methanolic and Aqueous Extracts}

The extracts were prepared according to the method described by Akinnibosun. ${ }^{13}$

\section{Preparation of Aqueous Extract}

Ten (10) $\mathrm{g}$ of dried grinded flower powder was measured out using an electronic weighing balance. It was dissolved in $100 \mathrm{~mL}$ of distilled water for 24 hours. Using a Whatman's filter paper No. 1, the resulting mixture was filtered to obtain a solid-free solution. A water bath was use to evaporate the filtrate to dryness and the resulting extract was collected using a sterile universal bottle. It was stored at $4^{\circ} \mathrm{C}$ in a refrigerator until when it is required for further use..$^{13}$

\section{Preparation of Methanol Extract}

Ten (10) $\mathrm{g}$ of dried grinded flower powder were suspended in 100 $\mathrm{mL}$ of $95 \%$ methanol for 24 hours. Using a Whatman's filter paper No. 1 , the resulting mixture was filtered to obtain a solid-free solution. The filtrate was evaporated to dryness and stored at $4^{\circ} \mathrm{C}$ until it is required for further use. ${ }^{13}$

\section{Extract Dilution}

After the extracts were prepared as described by Akinnibosun, the aqueous and methanol extracts were reconstituted using sterile distilled water to obtain the following concentrations: $200,100,50$, $25,12.5,6.25$, and $3.13 \mathrm{mg} / \mathrm{mL}^{13}$

\section{Sterility Test of Leaf Extract}

The extracts (methanol and aqueous) were tested for growth of contaminants according to the methods of Cheesebrough. ${ }^{14}$ Standard extract $(1 \mathrm{~mL})$ was inoculated aseptically onto nutrient agar and incubated at $37^{\circ} \mathrm{C}$ for 24 hours. The plates were observed for sign of growth. No growth on the plates signified sterility of the extracts.

\section{Phytochemical Screening of $H$. sabdariffa}

The sample was screened for the following compounds: alkaloids, phenols, terpenoids, saponins, tannins, flavonoids, glycosides, steroids, anthraquinones, etc. This was done following standard methods. ${ }^{15}$

\section{Test for Tannins}

Two (2) $\mathrm{g}$ of each extract were dissolved in $10 \mathrm{~mL}$ of distilled water in separate test tubes. Three (3) drops of $10 \%$ ferric chloride $\left(\mathrm{FeCl}_{3}\right)$ was added to $2 \mathrm{~mL}$ of the solution. The appearance of blackish-blue or blackish green coloration indicates the presence of tannins. 


\section{Test for Saponins}

About $0.1 \mathrm{~g}$ of each extract was dissolved in $5 \mathrm{~mL}$ of distilled water. The solution was shaken vigorously. The presence of saponin was indicated by the formation of frothing bubbles, which lasted for 10 minutes.

\section{Test for Alkaloids}

About $0.5 \mathrm{~g}$ of each extract was dissolved in three drops of Dragendoff's reagent. The presence of alkaloid was indicated by the formation of orange precipitate.

\section{Test for Flavonoids}

About $0.2 \mathrm{~g}$ of each extract was added to $2 \mathrm{~mL}$ of sodium hydroxide solution. The resulting solution was shaken vigorously to dissolve. The presence of flavonoids was indicated by the occurrence of a yellowish solution, which disappears on addition of hydrochloric acid $(\mathrm{HCl})$.

\section{Test for Glycoside}

Half $(0.5 \mathrm{~g}$ ) of each extract was added to $3 \mathrm{~mL}$ of Fehling solution and dissolved. The presence of glycosides was indicated by the formation of a brick red precipitate.

\section{Test for Steroids}

Five (5) drops of concentrated $\mathrm{H}_{2} \mathrm{SO}_{4}$ was added to $0.1 \mathrm{~g}$ of each extract in the test tube. The presence of steroids was indicated by the formation of a reddish brown coloration in the test tube.

\section{Terpenoids}

Four milligrams $(4 \mathrm{mg}$ ) of extract were treated with $0.5 \mathrm{~mL}$ of acetic anhydride and $0.5 \mathrm{~mL}$ of chloroform. Then concentrated sulfuric acid solution was added slowly and red violet color was observed for terpenoid.

\section{Anthraquinone}

To $10 \mathrm{mg}$ of the dissolved extract, magnesium acetate solution was added. Pink color developed, which indicates the presence of anthraquinone and no color change indicates negative.

\section{Antibacterial Assay}

The agar-well diffusion technique was used to carry out the antibacterial susceptibility of the plant flower extracts in comparison with standard antibiotic gentamicin $(20 \mathrm{mg} / \mathrm{mL})$ in vitro on the isolates according to the methods of National Committee for Clinical Laboratory Standards. ${ }^{16}$ Pure culture of the bacteria was grown on nutrient agar. Three colonies of each organism were pick into the Mueller Hinton broth (Oxoid, England), incubated for 4 hours at $37^{\circ} \mathrm{C}$, and diluted with sterile saline to a density visually equivalent to the MacFarland standard. Using a sterile 6-mm-diameter cork borer, four (4) wells were cut in the agar to which the two extracts of $H$. sabdariffa calyces were added, as well as the standard drug, gentamicin (GEN, $20 \mathrm{mg} / \mathrm{mL}$ ) and sterile water separately, which served as the positive and negative controls, respectively. For pre-diffusion to occur, the plates were placed on the bench for 30 minutes after which they were subsequently incubated for 48 hours at $37^{\circ} \mathrm{C}$. The zones of inhibition were then measured with the use of a calibrated ruler.

\section{Determination of Minimum Inhibitory Concentration}

The broth dilution method was used to determine the minimum inhibitory concentration (MIC) of $H$. sabdariffa flower extracts against the test organisms. To each $5 \mathrm{~mL}$ of the various extracts in different test tubes, $5 \mathrm{~mL}$ of nutrient broth each was added and serially diluted out to various concentrations ranging from 200 to $3.13 \mathrm{mg} / \mathrm{mL}$. A loop full of each test bacteria was inoculated into each of the test tubes and subsequently incubated for 24 hours at $37^{\circ} \mathrm{C}$. The lowest concentration of the leaf extracts that inhibited the growth of the organism was the MIC. ${ }^{14}$

\section{Determination of Minimum Bactericidal Concentration}

Briefly, $1 \mathrm{~mL}$ bacterial culture was pipetted from the mixture obtained in the determination of MIC tubes, which did not show any growth and were subcultured onto nutrient agar. They were subsequently incubated at $37^{\circ} \mathrm{C}$ for 24 hours. This was obtained by streaking out the samples from the MIC tubes that showed no visible growth on nutrient agar plates. The least concentration of the sample that showed no growth was noted and recorded as the minimum bactericidal concentration $(\mathrm{MBC}) .^{14}$

\section{Results}

Table 1 shows the phytochemical components of methanol and aqueous extracts of $H$. sabdariffa extracts. Phenols, anthraquinolones, terpenoids, tannins and glycosides were present in both extracts at varying concentrations. Alkaloids and flavonoids were present in high amount in methanol extracts and absent in aqueous extracts. There was absence of steroids in both extracts.

The antibacterial efficacy of both extracts of $H$. sabdariffa on S. aureus and E. coli is found in Table 2. The diameters of the zone of inhibition of $S$. aureus on AE at concentrations of 200, 100, 50, 25 , and $12.5 \mathrm{mg} / \mathrm{mL}$ are $20,18,1,1$, and $10 \mathrm{~mm}$, respectively. While the diameters of THE zone of inhibition of $S$. aureus on ME at concentrations of $200,100,50,25$, and $12.5 \mathrm{mg} / \mathrm{mL}$ are $24,22,20$, 17 and $15 \mathrm{~mm}$, respectively. The diameters of the zone of inhibition of $E$. coli on same concentrations of $\mathrm{AE}$ and ME are found in Table 2.

The MIC and MBC of leaf extracts of $H$. sabdariffa extracts on $S$. aureus and E. coli are found in Table 3. The MIC and MBC of AE on S. aureus are both $50 \mathrm{mg} / \mathrm{mL}$ while the MIC and MBC of AE on E. coli are 25 and $50 \mathrm{mg} / \mathrm{mL}$, respectively. That of the methanol extract on S. aureus and E. coli is found in Table 3.

\section{Discussion}

The phytochemical analysis indicates the presence of flavonoids, terpenoids, alkaloids, saponins, phenol, anthraquinolones, and tannins in varying concentrations in the methanol and aqueous extracts of $H$. sabdariffa. Alkaloids, saponins, tannins, flavonoids,

Table 1: Phytochemical composition of $H$. sabdariffa extracts

\begin{tabular}{lll}
\hline $\begin{array}{l}\text { Phytochemical } \\
\text { components }\end{array}$ & Methanol extracts & Aqueous extracts \\
\hline Phenols & +++ & ++ \\
Flavonoids & +++ & - \\
Steroids & - & - \\
Anthraquinolones & ++ & + \\
Terpenoids & + & + \\
Glycosides & ++ & ++ \\
Tannins & + & + \\
Saponins & - & ++ \\
Alkaloids & +++ & - \\
\hline,- absence; + , slightly present;,++ moderately present;,+++ highly \\
present & &
\end{tabular}


Phytochemical Constituents and Antibacterial Activities of H. sabdariffa L. Calyces (Zobo Flower)

Table 2: Antibacterial activities of methanol and aqueous extract of $H$. sabdariffa on S. aureus and $E$. coli

\begin{tabular}{|c|c|c|c|c|c|c|c|c|}
\hline \multicolumn{9}{|c|}{ Extract concentrations (zone diameter of inhibition in $\mathrm{mm}$ ) } \\
\hline Isolates & 200 & 100 & 50 & 25 & 12.5 & $+C$ & $-C$ & Extracts \\
\hline S. aureus & 20 & 18 & 16 & 12 & 10 & 17 & 0 & $\mathrm{AE}$ \\
\hline S. aureus & 24 & 22 & 20 & 17 & 15 & 17 & 0 & ME \\
\hline E. coli & 17 & 11 & 8 & 7 & 7 & 18 & 0 & $A E$ \\
\hline E. coli & 22 & 20 & 18 & 15 & 13 & 18 & 0 & ME \\
\hline
\end{tabular}

$\mathrm{AE}$, aqueous extract; $\mathrm{ME}$, methanol extract; $+\mathrm{C}$, positive control (gentamicin, $20 \mathrm{mg} / \mathrm{mL}$ ); $-\mathrm{C}$, negative control (sterile water)

Table 3: Minimum inhibitory and bactericidal concentrations of $H$. sabdariffa extracts on S. aureus and E. coli

\begin{tabular}{llll}
\hline \multicolumn{4}{l}{ Concentration of extracts $(\mathrm{mg} / \mathrm{mL})$} \\
\hline Isolates & MIC $(\mathrm{mg} / \mathrm{mL})$ & $\mathrm{MBC}(\mathrm{mg} / \mathrm{mL})$ & Extracts \\
\hline S. aureus & 50 & 50 & $\mathrm{AE}$ \\
S. aureus & 25 & 25 & $\mathrm{ME}$ \\
E. coli & 25 & 50 & $\mathrm{AE}$ \\
E. coli & 12.5 & 6.25 & $\mathrm{ME}$ \\
\hline
\end{tabular}

$\mathrm{AE}$, distilled water extract; $\mathrm{ME}$, methanol extract; $\mathrm{MIC}$, minimum inhibitory concentration; $\mathrm{MBC}$, minimum bactericidal concentration

phenols, and several other aromatics have the capability to resist microbial invasion. ${ }^{17}$ It is documented that the chemical structure of the phytochemicals plays an important role in determining antibacterial activity. For instance, flavonoids that are hydroxylated phenolic substance are produced by plants in response to microbial infection. They complex with extracellular and soluble proteins and also with the bacterial cell wall. ${ }^{18}$

Saponins too possess detergent-like properties, which may increase the permeability of bacterial cell membranes thereby facilitating antibiotic influx through the bacterial cell wall. ${ }^{19}$

Similarly, basic character of tannins enables them to bind with proteins and damage the bacterial cell membrane. Tannins also hinder microbial growth by precipitating microbial protein and make nutritional proteins unavailable. ${ }^{20}$ Thus, $H$. sabdariffa has been found to be the reservoir of phytochemicals and capable of exhibiting antibacterial activity against number of diseases. ${ }^{20}$

The absence of some phytochemicals might be due to differences in the polarity of the solvents, as the types of solvent used determined the kind of biologically active compounds that can be extracted from the plant. ${ }^{21}$

It has been reported that different solvents have different extraction capabilities. ${ }^{22}$ Ashok et al. ${ }^{22}$ reported that the best way to extract broad-spectrum antimicrobial compound from plant is by the use of methanol solvents. The differences observed between antibacterial activities of the extracts could be explained by their abilities to dissolve in different solvents. ${ }^{22}$

Results from this study show that the methanol extracts of $H$. sabdariffa calyces inhibited the growth of both test organisms than the aqueous extract in a concentration-dependent manner. The variation in the antibacterial activities is due to difference in the quantity of compounds present in those plant extracts. ${ }^{23}$ Similar result was discovered in the work of Ewansiha. ${ }^{24}$

Result from this work showed a greater zone of inhibition produced by the methanolic extracts (13-24 mm) of $H$. sabdariffa calyces at all concentrations used compared to that produced by the distilled water extract $(7-20 \mathrm{~mm})$. This indicates the possibility that $H$. sabdariffa could serve as a better and alternative drug to treat infections caused by S. aureus and E. coli compared to most conventional antibiotics used presently in the world. Similar result was discovered in the work of Fullerton et al. ${ }^{25}$

The MIC obtained shows that different concentrations were effective against the two test organisms. The generally low MIC and $\mathrm{MBC}$ values of methanol extracts against $S$. aureus and $E$. coli are an indication of their antibacterial potential. ${ }^{26}$ The different values obtained from the MBC of the leaf extract of $H$. sabdariffa calyces on E. coli and S. aureus confirmed that both extracts have varying phytochemical properties, and hence exhibit different inhibitory effects and bactericidal effects on the test organisms but less when compared to the standard used ${ }^{27}$ (Abubakar and Usman 2016). This could be further explained by the differences in the chemical composition of these extracts. ${ }^{23}$ Similar results were obtained from the works of Okereke et al. ${ }^{28}$ and Mungole and Chaturvedi, ${ }^{29}$ but contrasted with the work of Arvind and Alka, ${ }^{30}$ who posited that $H$. sabdariffa extracts exhibited bactericidal effects very well when compared to standard antibiotics.

\section{Conclusion}

From this study, it can be concluded that some secondary metabolites such as phenols, flavonoids, glycosides, tannin, saponin, terpenoids, alkaloids, and anthraquinolones present in $\mathrm{H}$. sabdariffa calyx were responsible for the inhibition of the bacteria observed in this present study and could also justify its use as an antimicrobial agent.

It can also be concluded that the methanol extract of $H$. sabdariffa calyx possesses more antimicrobial activity (13-24 mm) in a concentration-dependent manner than the aqueous extract (7-20 mm).

\section{References}

1. Olaleye MT. Cytotoxicity and antibacterial of methanolic extract of Hibiscus sabdariffa. J Med Plants Res 2007;1(1):9-13.

2. Zhen J, et al. Phytochemistry, antioxidant capacity, total phenolic content and anti-inflammatory activity of Hibiscus sabdariffa leaves. Food Chem 2016;190:673-680. DOI: 10.1016/j.foodchem.2015.06.006.

3. Mohamed R, Fernandez J, Pineda M, et al. Roselle (Hibiscus sabdariffa) seed oil is a rich source of gamma-tocopherol. J Food Sci 2007;72(3):S207-S211. DOI: 10.1111/j.1750-3841.2007.00285.x.

4. Fouda AM, Daba MY, Dahab GM. Inhibitory effects of aqueous extracts of Hibiscus sabdariffa on contractility of the rat bladder and uterus. Can. J Physiol Pharmacol 2007;85(10):1020-1031. DOI: 10.1139/Y07093.

5. Brickell C, ed. The Royal Horticultural Society A-Z Encyclopedia of Garden Plants. United Kingdom: Dorling Kindersley; 2008. p. 534.

6. Ohifueme AE, Kerem T, Ayodapo OK, et al. Antidiabetic activityguided isolation of gallic and protocatechuic acids from Hibiscus sabdariffa calyxes. J Food Biochem 2019. e12927.

7. Minahan J. The complete guide to national symbols and emblems. ABC-CLIO 2009. 4-8. 
8. Fakeye TO, Adegoke AO, Omoyeni OC, et al. Effects of water extract of Hibiscus sabdariffa, Linn (Malvaceae) 'Roselle' on excretion of a diclofenac formulation. Phytother Res 2007;21(1):96-98. DOI: 10.1002/ ptr.2019.

9. Ali BH, Al Wabel N, Blunden G. Phytochemical, pharmacological and toxicological aspects of Hibiscus sabdariffa L.: a review. Phytother Res 2005;19(5):369-375. DOI: 10.1002/ptr.1628.

10. De Boer HJ, Cotingting C. Medicinal plants for women's healthcare in Southeast Asia: a meta-analysis of their traditional use, chemical constituents, and pharmacology. J Ethnopharmacol 2014;151(2):747767. DOI: 10.1016/j.jep.2013.11.030.

11. Da-Costa-Rocha I, Bonnlaender B, Hartwig S, et al. Hibiscus sabdariffa L. - a phytochemical and pharmacological review. Food Chem 2014;165:424-443. DOI: 10.1016/j.foodchem.2014.05.002.

12. Abdallah E. Antibacterial efficiency of the Sudanese roselle (Hibiscus sabdariffa L.), a famous beverage from Sudanese folk medicine. J Intercult Ethnopharmacol 2016;5(2):186-191. DOI: 10.5455/ jice. 20160320022623.

13. Akinnibosun HA. Biotherapeutic potential of aqueous and ethanolic extracts of Solenostemon monostachyus (P. Beauv.) Brig. leaves on some vegetative Gram-negative bacteria. Biol Environ Sci J Trop 2009;6(3):33-37.

14. Cheesebrough M. Biochemical tests to identify bacteria. Laboratory practice in tropical countries. Cambridge Edition; 2002. pp. 63-70.

15. Trease GE, Evans WC. Pharmacognosy, vol. 378 13th ed., Britain: Bailliere Tindall; 1989. pp. 386-480.

16. "NCCLS" National Committee for Clinical Laboratory Standards. Performance Standards for Antimicrobial Susceptibility Testing; Seventeenth Informational Supplement, M2-A9 and M7-A7. Wayne, P.A., U.S.A, 2007.

17. Bonjar GH, Nik AK, Aghighi S. Antibacterial and antifungal survey in plants used in indigenous herbal-medicine of South East regions of Iran. J Biol Sci 2004;4(3):405-412. DOI: 10.3923/jbs.2004.405.412.

18. Dye C. After 2015: Infectious diseases in a new era of health and development. Philos Trans R Soc Lond B Biol Sci 2014;369(1645): 20130426. DOI: 10.1098/rstb.2013.0426.
19. Sunanda P, Anand K. A novel phytochemical, digoxigenin-3-O-rutin in the amelioration of I soproterenol-induced myocardial infarction in rat: a comparison with digoxin. Cardiovasc Ther 2012;30(3):125-135. DOI: $10.1111 / \mathrm{j} .1755-5922.2010 .00242 . x$.

20. Abirami S, Nishanthini K, Poonkothai M. Antimicrobial activity and phytochemical screening of the leaf extracts of Eucalyptus globulus. Int J Curr Pharm Res 2017;9:85-89. DOI: 10.22159/ijcpr.2017v9i5.22145.

21. Tiwari $P$, Kumar $B$, Kaur $M$, et al. Phytochemical screening and extraction: a review. Int Pharmaceut Sci 2011;1(1):98-106.

22. Ashok V, Gomashe PA, Gulhane MP, et al. Antimicrobial activity of Indian medicinal plants: Moringa oleifera and Saraca indica. Int J Curr Microbiol Appl Sci 2014;6(3):161-169.

23. Ezeifeka GO. Antimicrobial activities of Cajanus Cajan, Garcinia kola seeds and Xylopia aethiopica on pathogenic microorganisms. J Bio Sci 2004;1:49-154.

24. Ewansiha JU. Evaluation of the antimicrobial activity of roselle (Hibiscus sabdariffa L.) leaf extracts and its phytochemical properties. Peak J Med Plant Res 2014;2(1):1-5.

25. Fullerton M, Khatiwada J, Johnson JU, et al. Determination of antimicrobial activity of sorrel (Hibiscus sabdariffa) on Esherichia coli O157:H7 isolated from food, veterinary, and clinical samples. J Med Food 2011;14(9):950-956. DOI: 10.1089/jmf.2010.0200.

26. Elzein M, Fahal AM, Rani MD, et al. Qualitative and quantitative phytochemical analysis of Moringa oleifera (Lam) pods. Int J Curr Microbiol AppSci 2018;7(5):657-665. DOI: 10.20546/ ijcmas.2018.705.080.

27. Abubakar I, Usman A. Phytochemical and antibacterial investigations of moringa (Moringa oleifera) leaf extract on selected bacterial pathogens. J Microbiol Antimicrob 2016;8(5):28-33. DOI: 10.5897/ JMA2016.0361.

28. Okereke CN, Iroka FC, Chukwuma MO. Phytochemical analysis and medicinal uses of Hibiscus sabdariffa. Int J Herbal Med 2015;2(6):16-19.

29. Mungole A, Chaturvedi A. Hibiscus sabdariffa L.: A rich source of secondary metabolites. J Pharm Sci Rev Res 2011;6(1):83-87.

30. Arvind $M, A l k a ~ C$. Hibiscus sabdariffa $L$ a rich source of secondary metabolites. Med Plant Res 2011;6(1):1 